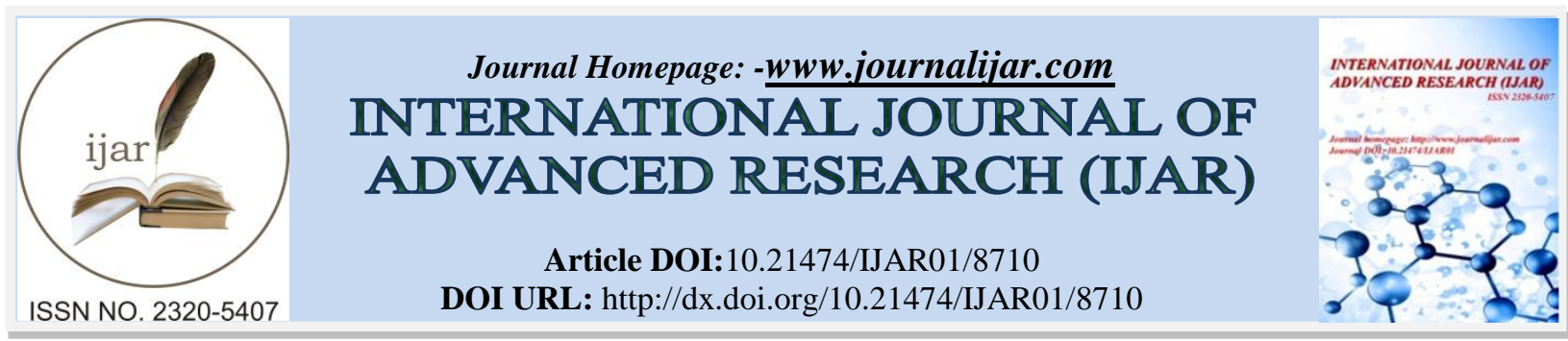

RESEARCH ARTICLE

\title{
DEVELOPMENT OF COUNSELING MODEL OF DERADICALIZATION PROGRAM IN INDONESIA: ALTERNATIVE FOR INTEGRATIVE COUNSELING MODEL FOR TERRORISM PRISONERS AS AN EFFORT TO PREVENT AND ERRADICATE THE CRIME OF TERRORISM IN INDONESIA.
}

Setyo Widagdo ${ }^{1}$ and Milda Istiqomah ${ }^{2}$.

1. lecturer at Law Faculty, Brawijaya University, Malang, Indonesia.

2. Doctorate Candidate at University New South Wales, Sidney Australia and lecturer at Law Faculty Brawijaya University.

\section{Manuscript Info}

….......................

Manuscript History

Received: 16 January 2019

Final Accepted: 18 February 2019

Published: March 2019

Key words:-

Prisoners Counselling, Deradicalization, Terrorism.

\begin{abstract}
The rise of the issue of the radicalism movement in Indonesia recently has made the Indonesian government necessary to review the strategies and efforts that have been made in order to quell the turmoil of radicalism. this research aims to contribute to the prevention of terrorism crime in Indonesia through the achievement of short-term research result, that is development of deradicalization program development model in Indonesia. The prevention aspect of crime of terrorism becomes the main objective in the formulation of the counselling model. The output of this research is the development of deradicalization counselling model for terrorism prisoners that can be used as an effort to prevent and eradicate terrorism in Indonesia. Therefore, the formulation of the counselling model is collaboratively arranged between research teams using participatory action research methods involving stake holders such as the Ministry of Law and Human Rights (KemenkumHam), the National Agency for Combating Terrorism (BNPT), Indonesian National Police (DENSUS 88), and Class 1 Penitentiaries in Surabaya and Malang as well as the prisoners of terrorism who are undergoing a term of punishment in Penitentiary. To obtain accurate data, this research will use qualitative method with sociological juridical approach by using in-depth interview technique and careful observation in the research location.
\end{abstract}

Copy Right, IJAR, 2019,. All rights reserved.

\section{Introduction:-}

The series of bombing incidents occurring in the territory of the State of Indonesia has caused widespread public fear, resulting in loss of life and loss of property, resulting in unfavorable influence on Indonesia's social, economic, political and relationships aspects with the international community. ${ }^{1}$

\footnotetext{
${ }^{1}$ Ellicitation on the Basic Legal Consideration in the Enactment of Law of Republic of Indonesia Number 15 Year 2003 on Eradication of Terrorism Crime.
} 
The bombing is one mode of terrorism that has become a common transnational phenomenon in some countries, organized and even an international crime that has a vast network that threatens national and international peace and security.

In the last twenty years, Indonesia has recorded dozens of bomb blasts on both small and large scale, which were mostly in Jakarta.

The bomb blast that occurred on Sunday 25 September 2011 in one of the churches in Solo Central Java brought back concerns about the unresolved issue of radicalism in Indonesia. $\mathrm{In}^{2}$ April of the same year, a suicide bombing also occurred in Cirebon City Resort Police Headquarters in the middle of a Friday prayer congregation at the mosque in the headquarter complex. ${ }^{3}$ With the appearance of two suicide bombings in less than a year, it clearly indicates that the government's strategy to eradicate the radical movement especially those affiliated with the religious terrorist movement is far from flawless.

The government's efforts in combating and tackling terrorism have never ceased until now. This effort is deemed by the government by issuing Law of the Republic of Indonesia Number 6 Year 2006 on Ratification of International Convention for The Suppression of The Financing of Terrorism, 1999. In addition, the government has also enacted Government Regulation in Lieu to Law No. 1 Year 2002, which was approved by the House of Representatives into Law No. 15 Year 2003 on Combating Terrorism Crime. Law No. 15 Year 2003 is in addition to regulating the material aspects, that also regulate formal. Therefore, this law is a special law (lex specialis) to the Book of Criminal Law and Criminal Procedure Code. With this law, it is expected to solve criminal cases related to terrorism from the material and formal aspects that can be done immediately.

Another effort is to provide assistance in the form of funds and training facilities by the government of neighboring countries, especially Australia, to the law enforcement officers, especially the Special Detachment 88 (hereinafter referred as DENSUS 88) as a special unit of terror prevention and eradication in Indonesia. The establishment of the Jakarta Center for Law Enforcement Cooperation (JCLEC) in Semarang, Central Java is a clear proof of Australian Government support in preventing and combating terrorism in Indonesia. No less than AUD \$ 36.8 million has been awarded to Indonesian government as a form of support for the eradication of the crime. ${ }^{4}$ However, these efforts and strategies are effective over a period of time but have not effectively eliminate the root causes of the radical movement.

Wtith the existence of criminal terrorism incidents that have occurred in Indonesia, the government should make a change in the punishment system of prisoners of terrorism crime. The change is mainly devoted to the model of guidance in the Penitentiary. The arrival of counselling model for prisoners in Penitentiary is due to the dynamics in the society. Correctional Institution (also referred as Penitentiary) works for prisoners who are given provisions in preparing for life after serving their sentence. The Penitentiary System began in 1964 supported by the Law of the Republic of Indonesia No. 12 Year 1995 on Corrections. The Penal Law reinforces the efforts to realizing a Penitentiary system which is a form of guidance for Prisoners in Correctional Institution. Activities within the Penitentiary are not merely to punish or guard the prisoners but include the process of counselling so that the targeted citizens are aware of their mistakes and improve themselves and not to repeat the criminal acts they had committed.

In this Penitentiary, the prisoners are given a counselling that one of them in the form of job training as a provision of life when they get free from the Penitentiary. The penal system has the function of establishing a Prisoner of Correctional Institution by improving itself, and not repeating the criminal act so it can be accepted by the

\footnotetext{
2 Bambang Dwi Marwoto, "Solo Diusik Ledakan Bom," Antara News.com (http://www.antaranews.com/berita/277016/solo-diusik-ledakan-bom) accessed on 10 February 2013.

${ }^{3}$ Ida Romlah, "Kapolresta Cirebon Jadi Target Utama Peledakan Bom," Tribun News.com (http://www.tribunnews.com/2011/04/15/kapolresta-cirebon-jadi-target-utama-peledakan-bom) accessed on 10 February 2013.

${ }^{4}$ Jakarta Center for Law Enforcement Cooperation (JCLEC), (http://www.jclec.com/index.php?option=com_content\&task=view\&id=14\&Itemid=28) accessed on 10 February 2013.
} 
community, actively participating in development, and able to live fairly as a good and responsible citizen. Therefore, Penitentiary is an estuary of the prisoners, especially for the perpetrators of criminal acts of terrorism.

However, previous studies revealed that Correctional Institution experienced many obstacles in the implementation of counselling, especially counselling given for prisoners of terrorism act. Among other, is the absence of specific guidance in conducting training programs for prisoners of terrorism. ${ }^{5}$ Class I Correctional Institution (Penitentiary) Surabaya, Sidoarjo, is one correctional institution which has special training program on Prisoners of terrorism. The stages in giving rehabilitation and special training in terrorism prisoners in this penitentiary, both physically and mentally, is performed by doctors, psychiatrists and psychologist. ${ }^{6}$ But in reality, the effort by giving this guidance does not provide maximum results given that some prisoners of terrorism was spreading out ideology and radicalism that so far they have adopted through the study that they arrange and attended by other prisoners (who were convicted for other crimes such as theft, murder, and others). ${ }^{7}$ Seeing the above condition, Surabaya Penitentiary officers cannot do much considering that getting a religious lecture and recitals is one of the rights that each prisoner has as in counselling. ${ }^{8}$

Associated with development efforts against terrorism prisoners, in some countries that have similar problems such as in Saudi Arabia, Yemen, and Singapore, the strategy they are doing is quite different. The prisoner is not only criminalized but coupled with the special treatment given after the prisoners had completed his sentence. Even to most of the terrorism prisoners, they obtained a process of rehabilitation in the community and an intensive persuasive approach both inside and outside of prison. Not only that, the prisoners are then provided with some funds to create jobs for themselves. In fact, it has been acknowledged by some countries that the efforts to restore terrorism prisoners which conducted in Saudi Arabia is the best counselling effort and can serve as a model for the development of counselling for prisoners, especially prisoners of terrorism. ${ }^{9}$

By examining the implementation of the de-radicalization program with many abovementioned obstacles, it is necessary to create a structured evaluation on the pattern and efforts of deradicalization in Indonesia, especially in the evaluation of the structure of the Penitentiary as the last estuary before prisoners were freed and plunge back into the community. This is considered very important as a reference material in an effort to reduce the turmoil of radicalism and terrorism in the future. The study and analysis of the counselling program will be used as reference material to develop the most appropriate counselling model to be applied to terrorism prisoners in Indonesia.

The purpose of this study was to analyze the legal structure, the pattern of policies and implementation of counselling for terrorism prisoners which will be, being, and has been implemented in Indonesia, as well as analyze an effective counselling model that can be applied to prisoners of terrorism as a prevention of criminal acts of terrorism in Indonesia.

\section{Method of Approach}

This study uses sociological juridical approach, that is a problem approach by reviewing the applicable regulations compared with the implementation of existing provisions in the field. ${ }^{10}$ This study examines or reviews the process of guidance of prisoners of penitentiary especially those sentenced to criminal cases of terrorism and prison officers within the scope of Class I Penitentiary Surabaya. So that we can know whether the implementation of deradicalization program in the case of terrorism prisoners has been in accordance with the objectives to be achieved or not. This study also aims to develop a new model of integrative counselling that appropriate to be applied to terrorism prisoners.

\footnotetext{
${ }^{5}$ Anne Dewi Riana, op cit, Pg. 73.

${ }^{6}$ Id.

${ }^{7}$ J Niniek Karmini, Teaching Jihad in Indonesian Prisons (2011) Jakarta Globe <http://www.thejakartaglobe.com/home/teaching-jihad-in-indonesian-prisons/449934> accessed on 8 September 2011.

${ }^{8}$ Milda Istiqomah and Muktiono, Evaluasi Program De-radikalisasi di Indonesia, Joint Resarch in Faculty of Law, Brawijaya University, 2012.

9 Adam Lankford dan Khaterine Gillespie, "Rehabilitating Terrorists through Counter-Indroctination: Lesson Learned from the Saudi Arabian Program.” International Criminal Justice Review vol. 21 no. 2 118-133, Sage Journals, June 2011.

${ }^{10}$ Ronny Hanitijo Soemitro, Metodologi Penelitian Hukum, Penerbit Ghalia Indonesia, 1988, pg. 34.
} 
The determination of population and sample in this research use purposive sampling technique that is determination of certain number of population and sample which had been determined by the researcher based on certain purpose and criteria or consideration.

This research uses descriptive analysis technique on the implementation of the process of deradicalization in terrorism prisoners case, that is by describing, analyzing, and evaluating obtained data from research result in the field, and linked to legal theory and the prevailing laws and regulations, which then analyzed to be drawn in a comprehensive conclusion.

\section{Discussion:-}

Policy Pattern Related to the Prevention and Eradication of Terrorism Crime in Indonesia: Policy Pattern of Prevention and Eradication of Terrorism Crime Conducted by the Police of the Republic of Indonesia

National Police of Republic Indonesia (hereinafter referred to as POLRI) is the guard for security in Indonesia. The tasks and responsibilities are to provide a sense of security to the state, society, and property from crimes and natural disasters.

In the case of the eradication of terrorism in Indonesia, POLRI also has an important role, especially with the establishment of a special anti-terror detachment named Special Anti-Terror Detachment 88 for (hereinafter abbreviated as DENSUS 88). The establishment of DENSUS 88 has a long history. It is related to the defense and security institutional system in Indonesia.

The momentum of the global campaign of war on terrorism has been a turning point for the strengthening and development of an established, reliable, and professional anti-terror institution. The strengthening of anti-terrorism institutions is ultimately carried out in POLRI institution, in addition to being a strategy to gain support and assistance from Western countries to continue to disburse aid to build anti-terror institutions, also because POLRI has been considered as an institution that capable of developing such anti-terror unit.

The rapid escalation of terror forced the Police to specialize in anti-terror issues on a special task force and resulted in the formation of POLRI's Task Force on Bombing, whose first task was to investigate the 2001 Christmas Bombing case, followed by other task on bombing threat. This Task Force of POLRI became so well known to the public when handling several bombing cases related to foreign affairs, such as Bali Bomb I, Bali Bomb II, Marriot Bomb, and Australian Embassy Bomb. This task force is under the Criminal Investigation Agency POLRI HQ.

The Policy Pattern on the Prevention and Eradication of Terrorism Crimes Conducted by the National Agency for Combating-Terrorism (BNPT)

The existence of a radical group of terrorism shows that there has been an elevation in the modus operandi and target of radical terrorism groups in Indonesia. The elevation is characterized by a shift in targeted attacks that no longer only target foreign interests or nation (fear enemy), but also national interest and the apparatus as the near enemy as its target. This elevation is characterized by making young people who are in the process of finding identity as a target to become perpetrators of terror by studying the technique of composing a bomd by himself (personal interpretation). The involvement of young people in this note is summarized by Maj. Gen. Agus Surya Bakti as Deputy of Prevention, Protection, and Deradicalization of BNPT in his paper entitled Terrorism Prevention Strategy that from the event of suicide bombing in Bali Bomb I to the event of Kepunton Church Bombing are conducted by youth with ages ranging $18-31$ years. ${ }^{11}$

Furthermore, to cope with terrorism, the governement formed National Agency for Combating Terrorism (BNPT).

According to a report from the International Crisis Group (ICG), in 2007, about 150 prisoners who were involved either directly or only as a change in the acts of terrorism in the period 2006 to 2007 have been released. ${ }^{12}$ To counter the return of these convicts back to the terrorism network, a de-radicalization effort is needed.

Dr. Petrus Reinhard Golose reveals three keys in the deradicalization program of ex-terrorists, those are humanist, soul approach, and touching the grassroots. ${ }^{13}$

\footnotetext{
${ }^{11} \mathrm{Id}$.

${ }^{12}$ International Crisis Group (ICG) reports "Deradicalisation and Indonesian Prisons, Executive Summary and Recommendation” Crisis Group Asia No. 142, 19 November 2007
} 
Humanist is the first deradicalization approach that directly touches terrorists and their families. When terrorists are arrested, they are immediately secured in a humane way, and their families are also noticed for their well-being.. The main factor of terrorism is deprivation: poverty, low education and political marginalization. The welfare of terrorist families is not considered. One example of the objective approach in the corridor of humanity is the family of Ali Ghufron, Imam Samudra, and Amrozi Nurhasyim or better known as the trio of Bali Bomb. Since the arrest of those three up to today, two years after they were executed in Nusa Kambangan, The children of those three terrorists must be nomad because of the stigma of a terrorist child. This certainly affects their mental.

Soul Approach is an approach where violence and intimidation to stop terrorism are not used. In contrast, the soul approach treats terrorism prisoners as human beings. Counselling methods by BNPT (National Agency for Combating Terrorism) leading to re-orientation and re-education. In re-orientation and re-education, ex-converted terrorist is empowered to reassure his unconverted fellow terrorist. One of the success stories in this soul approach is Ali Imron, one of the first Bali Bomb executors who took place in 2002. In his book "Ali Imron The Bomber", Ali Imron admitted that plunging into terrorism was a mistake, and at the end of his book he apologized to the family of the victim.

Touching the Grassroots. This program is not only aimed at suspects and terrorism convicts, but it is also directed towards sympathizers and community members who have been exposed to radical understandings, and instill multiculturalism to the wider community.

Director of Deradicalization of the National Agency for Combating Terrorism, Irfan Idris on one occasion mentioned, the deradicalization program has a wide scope. In 2013, this program not only reaches in pesantren, but also in places of worship, religious education institutions, universities, high schools, and junior high schools. ${ }^{14}$

Dr Carl Ungerer, a researcher at the Australian Strategic Policy Institute, once mentioned that 30 percent of terrorism prisoners in Indonesia are not de-radicalizing. As a result, some terrorism prisoners still intend to commit terror after being released from prison. Ungerer's findings make sense, because the deradicalization that has been done is still considered sporadic. Deradicalization that has been running still has a lot of weakness, although it cannot be said there is no benefit. The disadvantages include sporadic and unintegrated execution. Therefore, it needs for proper deradicalization process so that the problem of terrorism and radical understanding in Indonesia can be resolved appropriately. ${ }^{15}$

In order to prevent terrorism, BNPT takes a role by conducting a preventive program consisting of two layers, they are deradicalization and counter-radicalization strategy. ${ }^{16}$ The deradicalization strategy is aimed at "harm reduction" aimed at a handful of children of the nation who have been exposed and actively involved in carrying out acts of terrorism both individually and in groups. The program is specifically meant to open and change the previously narrow fanatical horizon of thinking into accepting differences. In addition, the deradicalization program teaches peaceful teachings of religion, pluralism in society, and the provision of national insight which is carried out continuously by involving elements of civil society. The deradicalization process uses a process of persuasive approach (soft approach), among others, with the process of rehabilitating ex-terrorism in prisons with religious and cultural approach to the former perpetrators of terrorism. ${ }^{17}$

Meanwhile, the process of rehabilitation is implemented simultaneously with re-education and re-socialization aimed at prisoners of terrorism. The program aims to prepare former terrorism actors to be ready to return and blend into society.

\footnotetext{
${ }^{13}$ Dr. Petrus Reinhard Golose, Deradikalisasi Terorisme, Yayasan Pengembangan Ilmu Kepolisian, 2009

${ }^{14} \mathrm{http} / / / \mathrm{www}$. shnews.co/detile-19242-program-deradikalisasi-patut-dipertanyakan.html, accessed on 22 August 2013.

${ }^{15} \mathrm{Id}$.

${ }^{16}$ Result of interview with Major General Agus Surya Bakti, Deputy of BNPT for Prevention and Deradicalization of Terrorism Division, on 7 October 2013 at 11.00 WIB.

${ }^{17}$ Id.
} 
Until now, the center of deradicalization program is still under development, but BNPT acknowledges that they still have no concept related to the implementation of the deradicalization program. Basically, BNPT already has several deradicalization concepts that have been successfully implemented by some countries, but with the unification of facilities, infrastructure, and regulations that become the main obstacle, so BNPT still unable to implement it in Indonesia. $^{18}$

While the counter radicalization program is a program aimed at the wider community with a focus on leaders and organizations among the community, youth, the elements of education, and the religious elements. The program aims to strengthen the resilience of the community so as not to be easily infiltrated by radical groups and radical ideology of terrorism. ${ }^{19}$ This is because terror groups tend to strategically and rationally conduct in a communal rather than individual as described by Rex A. Hudson in his book, "The Sociology and Psychology of Terrorism: Who Becomes A Terrorist and Why". ${ }^{20}$

Usually a community of terror groups, making the neighborhood of citizens an ideal hideout for terror groups to keep track of them and can carry out their acts of terror. This was evident during the terrorism experiments in Jatiasih, Tmabora, and Beji that the terror group turnt a house in the settlements as a place for bomb assemblies as well as safe havens with the camouflage.

Thus, BNPT also has the responsibility to conduct socialization related matters that can actively prevent members of the community, especially students and elements of education in order not to be exposed and influenced by misguided understanding. Various ways are done, such as through intensive and qualified communication in the family and formal education, dialogue forums for strengthening national insight, achievement in academic and nonacademic fields, and empowering and applying the value of local wisdom growing in the community are examples of simple things that should continue to be socialized and carried out by all components of the nation. ${ }^{21}$

\section{Implementation of Counselling Towards Terrorism Prisoners as an Effort of Prevention to the Ciminal Act of Terrorism in Indonesia}

Recidivism in the crime of terrorism is one of the problems in the eradication and prevention of terrorism that is very actual and urgent to be addressed at this time. ${ }^{22}$ The existence of recidive terrorist and new terrorist suspects can be an indicator that the integrated criminal justice system, especially its criminalization, has in some cases failed to achieve its objectives. The purpose of crime which becomes a benchmark in the assessment of to which extent the achievement of the objectives of the integrated criminal justice system are as follows: ${ }^{23}$

1. Enforcing the rule of law and protecting the public which largely dependent on coercion;

2. Reformation. Providing awareness of the prisoner to the wrongdoing and then becoming a good and useful person so that it can be accepted by the community later;

3. Restraint. Restricting the connection between prisoners and the public to protect security and public order;

4. Retribution. Retaliation against the offender shall be in harmony with the offense he committed;

5. Deterrence. Bringing a deterrent effect for the perpetrator not to repeat the crime or to make others afraid, so he does not commit a similar crime.

These five objectives must be interconnected with one another so that the success or failure of a single destination is bound to be related, influential, and influenced by other purposes. Legal order is difficult to be realized if the detterence effect and the reformation effect do not include ex-prisoners so resulting in the emergence of recidivists. Likewise, the deterrence effect will be influenced by restraint and retribution factors. This suggests that it is true that the elements involved in criminal justice constitute a unified entity and can not be separated from one sub-system to another.

\footnotetext{
${ }^{18}$ Result of interview with Major General Agus Surya Bakti, Deputy of BNPT for Prevention and Deradicalization of Terrorism Division, on 7 October 2013 at 11.00 WIB.

${ }^{19}$ Id.

${ }^{20}$ Rex A Hudson, The Sociology and Psyhology of Terorism:Who Becomes A Terorist and Why, Faderal Research Division Library of Congres, Washington, 1999, pg 16.

${ }^{21}$ Op cit, pg. 3.

${ }^{22}$ http://nasional.kompas.com/read/2011/07/25/11141865/.Mantan.Napi.Teroris.Kembali.Meneror

${ }^{23}$ Hamzah, Andi.Asas-Asas Hukum Pidana di Indonesia. PT. Sofmedia, Jakarta. 2012. pg. 36-38
} 
As a system, the relationship between sub-systems within the integrated criminal justice system can be explained by using three approaches: ${ }^{24}$

\section{Normative Approach}

Looking at those four law enforcement apparatuses (police, prosecutors, judges, and the penitentiary officers) as institutions that implement the prevailing law regulations, so that the four apparatuses are an integral part of the law enforcement system solely.

Administrative Approach

Looking at the four law enforcement apparatuses as a management organization that has a working mechanism both horizontal and vertical relationships in accordance with the organizational structure prevailing within the organization.

Social Approach

Looking at the four law enforcement officers as an integral part of a social system, so that society as a whole is responsible for the success or failure of the four law enforcement apparatuses in performing their duties.

In order to achieve these objectives, the criminal justice system has the following duties: ${ }^{25}$

1. preventing people from becoming victims of crime,

2. solve the crime, so that the people are satisfied that justice has been established and the guilty are convicted

3. trying to keep those who have done evil do not repeat their actions.

With these defined objectives, tasks, and gaps that exist between system ideality and practical reality in the integrated criminal justice system in Indonesia, especially in terrorism prisoners, it is necessary to further examine the phenomenon from the side of terrorism prisoner administration in penitentiary. In the early stages, once a defendant of a terrorism crime receives a verdict from a judge in a court, the next process is the execution or decision of the judgment by changing the status of a convicted terrorist into a terrorism prisoner. Prisoneers of terrorism will then enter a new chapter in their life that will have an unfree live (restraint) in a penitentiary (formerly called prison) as a consequence of punishment or criminal sanction received for his actions.

From the previous discussion revealed the fact that for criminal case of terrorism as an extraordinary crime both in material criminal and formal criminal, has some differences with other criminal cases so that in the process of investigation, prosecution, and examination of the case in court also has its own peculiarities. Obviously, to achieve the purpose of penalization proceedings in the court is not the final estuary in the process of settling criminal cases of terrorism in the perspective of terrorism as an existing social conflict in society that will be resolved systemically through an integrated criminal justice system. The next decisive step is the handling of terrorist prisoners in the penitentiary system as a process of creating reformation, retribution, restraint, and deterrence to terrorism prisoners, as well as for its social impact.

Based on the observations from the officers of counselling in Class 1 Correctional Institution, the prisoners of terrorism have a religious ideology that is different from ordinary people. ${ }^{26}$

Prisoners of terrorism generally have a violent ideology of thinking that their crime is a jihad which is a struggle to defend religion. In addition to possessing violent ideologies, prisoners of terrorism also have closed attitudes with other prisoners and even closed to the proper counselling programs that must be taken. But not all prisoners of terrorism have a closed characteristic, some are open to the environment around the Penitentiary. Prisoners of

\footnotetext{
${ }^{24}$ Geofrey Hazard Jr., dalam Sanford Kadish, Encyclopedia of Crime and Justice, vol. 2, pg. 450 in Romli Atmasasmita, Sistem Peradilan Pidana : Perspektif Eksistensialisme dan

Abolisionisme, (Bandung : Binacipta, 1996), pg. 17-18

${ }^{25}$ Norval Morris,"Introduction", in Criminal Justice in Asia, The Quest For An IntegratedApproach,Unafei, 1982, pg 5 in Mardjono Reksodiputro, Mengembangkan Sistem Pendekatan Terpadu Dalam Sistem Peradilan Pidana (Suatu Pemikiran Awal), Kriminologi Dan Sistem Peradilan Pidana, ( Jakarta : Pusat Pelayanan dan Pengabdian Hukum Universitas Indonesia, 2007), pg. 140. Cited from Thesis, Pg.

${ }^{26}$ Result of Interview with the Head of Guidance for Community's Security Section, M. Alfan. on 17 October 2013 in Class I Correctional Institution Surabaya.
} 
criminal acts of terrorism who have a closed characteristic to the environment are approximately 5 people, and those who are open to the environment are numbered approximately 10 people. ${ }^{27}$

The officers of penitentiary, by looking at the charcteristic of the terrorists who have such attributes, divide them into separate Room Blocks from other prisoners. The separation of the cell block serves to facilitate the officers to conduct surveillance to terrorism prisoners. Although it is also based on the stages of supervision to the different levels of prisoners at each stage of counselling, but the supervision given to all terrorism prisoners is the same, that is Maximum Security. With such supervision, all activities carried out by Prisoners of terrorism are always monitored by officers or other prisoners who are trusted to be spies. ${ }^{28}$ This is done to avoid the prisoners of terrorism acts to spread the ideology of jihadism to other prisoners in Penitentiary Surabaya. Room placement to Prisoners of terrorism is also different from other prisoners. Every 1 (one) prisoner of terrorism occupies 1 (one) room in a special block designated for terrorism prisoners. The separation of blocks and rooms is done to avoid any spread of radical ideology by terrorism prisoners to other, prisoners who are aiming to prepare a new "bridegroom" as a suicide bomber to commit acts of terror that will be done after the prisoner finished serving his sentence and leaving the penitentiary. ${ }^{29}$

With Maximum Security surpervision, there are still some activities performed by terrorism prisoners in Penitentiary Surabaya who tend to worry, such as reading jihad-themed books, watching videos of mujahideen warfare, and study the reading and writing of Qur'an conducted on terrorist block for other prisoners. There is discretion for prisoners of terrorism in receiving visits from general prisoners from other blocks, especially for reasons of teaching to read and write Al-Qur'an for other prisoners. If the surveillance is not serious enough, then this kind of leniency will bring a devastating effect in the future. Da'wah is an instrument to recruit followers. In prisons, even the smallest medium could be a space for prisoners of terrorism act to recruit sympathizers from other prisoners.

This occurred at Penitentiary Surabaya in Porong, there was an indication that there had been a spreading of radical ideology to prepare the "potential perpetrators" to carry out the ensuing suicide bombings. However, after 2 weeks of the discovery, 2 persons who are indicated to be prepared as bomber were immediately transferred to another separate Penitentiary. ${ }^{30}$

One of the counselling programs conducted at Surabaya Penitentiary is a Law Awareness Development Program by providing legal counseling aimed at achieving high levels of legal awareness in the life of the community. This legal awareness raising program aims to acknowledge prisoners in the penitentiary, especially prisoners of terrorism, to recognize their rights and obligations in order to participate in upholding the law and justice, order, peace, legal certainty, and the development of law-abiding behavior in every Indonesian citizen.

In relation to the implementation of counselling programs in prisons, there is one distinction of counselling program given to prisoners of terrorism crime, that is the existence of deradicalization program. Deradicalization program is a process to reduce the level of radical attitude possessed by terrorism prisoners. The program was conducted by Counsellor in Class 1 Correctional Institution Surabaya, in cooperation with National Agency for Combating Terrorism (BNPT).

The goal of the deradicalization program is to change the understanding of jihad believed by terrorism prisoners to be not as radically as before anymore. In carrying out this deradicalization program, the counselling officers also involve religious figures and non-governmental organizations. However, this deradicalization program has not been a fixed agenda in the guidance program for prisoners of criminal acts of terrorism in Class I Penitentiary Surabaya.

Deradicalization counselling program is usually done directly by lecture, discussion, demonstration and legal simulation. Another program that had ever undertaken by the Counselling Officer is by Performing Shadow Puppet (Wayang Kulit) show. Class I Penitentiary Surabaya held a Wayang Kulit show performance in cooperation with the

\footnotetext{
${ }^{27}$ Id.

${ }^{28}$ Result of interview with the Head of Counselling Division, Eddy Turyono, on 17 October 2013 in Class I Correctional Institution Surabaya.

${ }^{29} \mathrm{Id}$.

${ }^{30} \mathrm{Id}$.
} 
National Agency for Combating Terrorism (BNPT). ${ }^{31}$ The Wayang Kulit show was held on Sunday, April 3rd 2011. The mastermind of in the Wayang Kulit show was Ustadz Sonhaji from Pesantren Al -Irsyad.

The National Agency for Combating Terrorism (BNPT) carried out the Wayang Kulit show in order to wrap the deradicalization program and the implementation of counselling program in the field of legal awareness raising to the prisoners of terrorism. With this Wayang Kulit performance, it is expected that there will be a change within the prisoners of terrorism crime. The expected change is to align the understanding of jihad from the prisoners of terrorism, from the radical to be not radical anymore. However, the deradicalization program that packed in this Wayang Kulit show failed to get maximum results. The prisoners of terrorism do not understand the Wayang Kulit show which performed in Javanese language, and they closed theirselves and did not want to receive information from the government which they considered as taghut. ${ }^{32}$

However, the counselling given by Surabaya Penitentiary officers did not only focused on reducing the prisoner's understanding of radical ideology. As with other prisoners, the counselling officers also provide job training activities to improve the skills of prisoners, including: skills to support independent enterprises and skills to support small industry enterprises.

During the duration of the sentence, the prisoners of terrorism are still allowed to receive visits from family and certain people. ${ }^{33}$ This is in accordance with the principle of ensuring the right to remain in contact with certain families and individuals. Prisoners of terrorism usually receive visits from wives, children, and other relatives. The place for of visitation for prisoners of terrorism is the same place as for other prisoners, there is no difference with the other prisoners who are placed in the same place and mingle. However, although the venue of visitation is equated, the oversight given to the Prisoners of terrorism is different. The supervision provided by the Penitentiary Security Officers to the Prisoners of terrorism is tighter than any other prisoner upon receiving the visit.

Broadly speaking, the counselling given by Surabaya Correctional Institution to the Prisoners of terrorism crime is considered not maximal yet. This is because the counselling program gives more emphasis on security only, so it does not meet the requirement in the process of counselling to remind prisoners of terrorism crimes to his mistakes that have been made, and the preparation to be accepted back to the community, can actively play a role in development, and can live a reasonable life as a good and responsible citizen after the expiration of his punishment. The counselling given by the Correctional Institution in particular related to the deradicalization program is ignored by terrorism prisoners. As expressed by the terrorism prisoner that if he has finished his penalty, then he will return to his group and continue to fight and do jihad for the upholding of the Islamic State in Indonesia. ${ }^{34}$

If reviewed then the effectiveness of the counselling mechanism in the penitentiary will certainly depend on the relevance of the main problems of the character of terrorism prisoners who are very different from other criminal prisoners. As quoted by Sarlito Wirawan Sarwono in Terorisme di Indonesia (2012) about research findings by Roy J. Eidelson ${ }^{35}$ and Judy I. Eidelson that concluded the existence of 5 (five) dangerous ideas which at a certain level and situation can be the cause of the emergence of violence or intolerance between groups which can also be one of the causes or the basis of the occurrence of terrorism. The five dangerous ideas include:

\section{Superiority}

Superior feelings can stem from a number of things, and one of them is the belief that a group (religion, race, nation, etc.) is God's chosen group on earth and has some privileges compared to the other groups. The group sees the other groups as inferior, the infidel whose blood can be spilled, the manifestation of demons in the world so should not be

\footnotetext{
${ }^{31}$ Result of interview with terrorism prisoners in Penitentiary Surabaya on 19 October 2013.

${ }^{32}$ Result of interview with terrorism prisoners in Penitentiary Surabaya on 19 October 2013.

${ }^{33}$ The Law of the Republic of Indonesia Number 12 Year 1995 on Correction, in Article 5 Letter G reads: "The penitentiary system shall be implemented based on the principle:

a. Protection; b. equality of treatment and service; c. education; d. mentoring; e. respect for human dignity and prestige; f. loss of independence is the only suffering; g. ensuring the right to remain in contact with certain families and individuals."

${ }^{34}$ Result of interview with terrorism prisoners in Penitentiary Surabaya on 19 October 2013.

${ }^{35}$ Roy J. Eidelson and Judy I. Eidelson.Dangerous Ideas: Five Beliefs That Propel Groups Toward Conflict. Journal of the American Psychological Association, Vol. 58, No. 3, 182-192. March 2003
} 
pitied, ruled, hated, or even fought. Some terrorist groups often use slogans that reflect that they are a group that has the authority to uphold the supreme law on earth, and for those who do not accept necessarily have consequences to be hostile and fought. These feelings and acts of hostility to them are the form of supreme devotion, and this devotion is a noble glory before God, or their leader for a group who are not based on a divine ideology.

\section{Injustice}

Feelings of injustice can also trigger a form of resistance that can, in some degree, be physical actions such as demonstrations, boycotts, assaults, and even terrorism activities. Injustice, for groups based on religious bonds, is not limited by the boundary of citizenship, but is bound only by the similarity of beliefs or religion so it works globally. The feeling of injustice to a group in Indonesia can arise because of unfair actions in Afghanistan. Similarly, the injustice feeling within the people in Indonesia can lead to terrorism acts by groups originating from Malaysia, and so on.

\section{Vulnerability}

Situations that cause a group to experience anxiety about their future because of a situation that weakens their lives will give rise to the nature or feeling of resistance as a form of self-defense so that it becomes legitimate to call for hostilities, war, and terrorism.

\section{Mistrust}

Mistrust between a group and another group, and in this case can be a state or government that controls them might potentially be a trigger for social conflict. Terrorist groups have always been unconvinced by government or state policies that are considered illegitimate by their beliefs, and on the contrary, the government or state is always repressive against the group which considered as terrorists as always accused to threaten the sovereignty and security of the state.

\section{Powerlessness (helplessness)}

Groups that themselves feel helpless can easily build their internal solidarity and arouse the spirit of struggle in achieving equality or even superiority. Revolution can also be triggered by powerlessness due to imperialism or colonialism resulting in solidarity of mutual resistance. In a positive side, a nation or country can use feelings of helplessness against colonialism. But on the extreme, feelings of helplessness can instead be abused to ignite the spirit of intolerance, hostility, and acts of terrorism for reasons of injustice.

The five ideas do have in common with the reasons used by terrorism prisoners when they commit acts of terrorism such as the reason for the superiority of their religious teachings so that it becomes the only religion that must rule on earth. In addition, they also feel to be the victim of injustice both, at the national and global levels, so they have to defend themselves in ways that they think is in accordance with the religious teachings. Similarly, with their very high mistrust to the system and practice of government or state administration, so that there is a need for changes in the system based on values they embrace.

Concerning the feeling of helplessness, in some instances, it is not directly revealed but from their implicit claims it can be concluded that they feel powerless against the power of the state supported by the military and police and its international allies, so that the only relevant mechanism of physical resistance is a silent assault such as bombing action. ${ }^{36}$ Beyond the theological perspective, of course, the psychological aspect can be used as a benchmark on how to build radicalism that can lead to acts of terrorism or at least support it without a judgement (passive supporter) which in time also has the potential to form an alliance (active supporter).

Normatively, the six topics of counselling (religion, nationalism, intellectuality, legality, personality, and selfreliance) in the process of correction treats the same treatment to all prisoners despite having different backgrounds. Likewise, the curriculum and its implementation process do not make differences either to common prisoners (perpetrators of public crimes) and special prisoners including terrorism prisoners. ${ }^{37}$ Materials of religious guidance which delivered in the method of seminary in the penitentiary mosque as an example, will be submitted predominantly to the appointed cleric or kyai by the penitentiary officer and the penitentiary only knowing what

\footnotetext{
${ }^{36}$ Result of interview with terrorism prisoners in Class I Penitentiary Malang on 13 November 2013.

${ }^{37}$ Interview with Ali Musthofa, Head of Counselling Division in Class I Penitentiary Malang on 5 November 2013
} 
material will be delivered without the process of in depth and measurable analysis on the needs by the penitentiary. ${ }^{38}$ Even some prisoners of terrorism become antipathy to some preachers who are deemed inconsistent with their religious understanding, especially for preachers who are affiliated to the Islamic organization such as Nahdhotul Ulama or Shi'i. ${ }^{39}$ And even there is prisoner of terrorism who have long inhabited the penitenteiary and now is called ustadz, both by prison officers and his fellow prisoners because his capacity of religious knowledge is considered adequate, so that he got some "santri" (students) from other prisoners to learn Islam, especially the Al-Qur'an reading and understanding of meaning. ${ }^{40}$ Therefore, it is natural to see that terrorism prisoners have authority in the presence of other prisoners and even prison officers also seem reluctant to them.

Awareness of nationality and state is also a serious problem in the counselling of terrorism prisoners because the main reason from the beginning they are involved in terrorist groups is the assumption that the current Indonesian government has deviated from the teachings of religion and became the henchmen or extension of the western's hand and the United States' hand (thoghut), so they deem it legitimate to be fought through the path of terror. ${ }^{41}$ Their ideology is so strong that it is the consequence of the struggle and also the opportunity for them to further strengthen their faith and their religious understanding. ${ }^{42}$ And furthermore, they also have not been able to accept the justification of Pancasila as the foundation of the state, so that the concept of the Indonesian state today is not the country they want, either conceptually or much less in the practice (such as corruption, police torture, bribery in prisons, and engineered judiciary).

The counselling to the awareness of nationality and state towards of terrorism prisoners with the type of extreme ideology, both in material and delivery methods, is certainly not the same with the other prisoners. Even the problem of ideology is a very serious problem in the process of deradicalization of both prisoners and ex-terrorism prisoners because it involves the perspective or paradigm of thinking, beliefs, and life experiences, so long that it cannot be changed in a short time during in the penitentiary. ${ }^{43}$ Equalization of national and state awareness raising for inmates of terrorism with other prisoners can be an indicator that there is no relevant adjustment between the fostering instruments in the prison process in prisons with other sub-system developments (investigation, prosecution, judiciary) in the integrated criminal justice system in particular criminal act of terrorism. Under such circumstances, in the context of terrorism prisoners, it should be a very serious evaluation to the existence and achievement of the first code of the prisoner's "code of conduct" contained in the "Catur Dharma" of Prisoner which reads, " We, Prisoners, promise to be a moral human being with Pancasila and become an active and productive Human in development". ${ }^{44}$

\section{Conclusion:-}

The conclusion of this research is:

That the government agencies (stakeholders) involved in the handling, prosecution, and prevention of criminal acts of terrorism have not implemented a program of deradicalization in maximum. Ministry of Law and Human Rights, BNPT, and POLRI have a slightly different program on the deradicalization program.

\footnotetext{
${ }^{38}$ Result of interview with Khoirul as Penitentiary officer who take role as the manager of Mosque in Class I Penitentiary Malang, 5 November 2013

${ }^{39}$ Id.

${ }^{40} \mathrm{Id}$.

${ }^{41}$ Sarwono, Sarlito Wirawan. Terorisme di Indonesia. PT. Pustaka Alvabet, Jakarta. 2012. Pg. 7-43

${ }^{42}$ Result of interview with Terrorism Prisoner, Moh. Cholily Hanif (involved in hiding Dr. Azhari) in Class I Penitentiary Malang, 13 November 2013

${ }^{43}$ Sarwono, Sarlito Wirawan. Op. Cit. Pg. 133

${ }^{44}$ Chapter III on the objectives of Counselling Model for Prisoner/Convict (Decision of Ministry of Justice of the Republic of Indonesia Number: M.02-PK.04.10 Year 1990)
} 


\section{Reference:-}

1. Adam Lankford dan Khaterine Gillespie, "Rehabilitating Terrorists through Counter-Indroctination: Lesson Learned from the Saudi Arabian Program.” International Criminal Justice Review vol. 21 no. 2 118-133, Sage Journals, June 2011.

2. Agus Surya Bakti, Strategi Pencegahan Terorisme, Disampaikan dalam diskusi ilmiah di Universitas Kristen Satya Wacana, Salatiga, Pada tanggal 17 Oktober 2012

3. Bambang Poernomo, 1986. Pelaksanaan Pidana Penjara dengan Sistem Pemasyarakatan. Yogyakarta: Liberty,

4. Burhan Ashshofa. Metode Penelitian Hukum. Rineka Cipta. Jakarta. 2004.

5. Burhan Bungim, Metodologi penelitian Kualitatif, PT. Raja Grafindo Persada, Jakarta, 2001.

6. Intan Nur Nugraheni, Kendala yang Dihadapi lembaga Pemasyarakatan dalam pembinaan Narapidana Kasus terorisme, Skripsi, 2010

7. Loebby Loqman, Analisis Hukum dan perundang-undangan Kejahatan terhadap Keamanan Negara di Indonesia, 1990. Jakarta: UI Press.

8. Milda Istiqomah dan Muktiono, Evaluasi Program De-radikalisasi di Indonesia, Joint Resarch Fakultas Hukum Universitas Brawijaya, 2012.

9. Petrus R Golose, Counter Terrorism in Indonesia, Makalah dipresentasikan dalam Seminar Internasional :Terrorism: Redefining, Preventing and Combating" pada tanggal 23-24 Juni 2011, Fakultas Hukum Universitas Brawijaya.

10. Petrus Reinhard Golose, Deradikalisasi Terorisme, Yayasan Pengembangan Ilmu Kepolisian, 2009

11. Rex A Hudson, The Sociology and Psyhology of Terorism:Who Becomes A Terorist and Why, Faderal Research Divisin Library of Congres, Washington, 1999

12. Ronny Hanitijo Soemitro, Metodologi Penelitian Hukum, Penerbit Ghalia Indonesia, 1988.

13. Romli Atmasasmita, Sistem Peradilan Pidana : Perspektif Eksistensialisme dan Abolisionisme, (Bandung : Binacipta, 1996)

14. Roy J. Eidelson and Judy I. Eidelson.Dangerous Ideas: Five Beliefs That Propel Groups Toward Conflict. Journal of the American Psychological Association, Vol. 58, No. 3, 182-192. March 2003

15. Siti Rahayu. 1983. Suatu Tinjauan Ringkas Sistem Pemidanaan di Indonesia. Jakarta: Akademi Pressindo.

16. Sarwono, Sarlito Wirawan. Terorisme di Indonesia. PT. Pustaka Alvabet, Jakarta. 2012.

17. Soerjono Soekanto, dkk. Penelitian Hukum Normatif, CV. Rajawali, Jakarta, 1985.

18. Soedarmayanti \& Hidayat.Metodologi Penelitian. Mandar Maju. Bandung. 2002.

19. Sugeng Riyadin yang berjudul "Lembaga Pemasyarakatan Terbuka Sebagai Sub-sistem dalam Sistem Peradilan Pidana Terpadu (Studi Khusus tentang Lapas Terbuka Jakarta), Program Pasca Sarjana Ilmu Hukum, Fakultas Hukum Universitas Indonesia. 2012.

20. Taufik Andri, Deradikalisasi atau Disengagment Kajian dan Praktek Civil Socety

21. Anne Dewi Rianna, Pembinaan Terhadap Narapidana Pelaku Tindak Pidana Terorisme Pada Lembaga Pemasyarakatan (Studi Lembaga Pemasyarakatan Klas 1 Surabaya),Skripsi, Fakultas Hukum Universitas Brawijaya, 2012.

22. Peraturan pemerintah pengganti Undang-Undang Republik Indonesia Nomor 1 tahun 2002 tentang Pemberantasan Tindak Pidana Terorisme, yang diubah menjadi Undang-Undang Republik Indonesia Nomor 15 Tahun 2003.

23. Undang-Undang Nomor 12 tahun 1995 tentang Pemasyarakatan. 